Document downloaded from:

http://hdl.handle.net/10251/122232

This paper must be cited as:

Aparicio Herrero, F.; Aramburu, J.; Herranz Gordo, MDC.; Pallás Benet, V.; López Del Rincón, C. (2018). Parietaria mottle virus: a potential threat for tomato crop?. Acta Horticulturae. 1207:261-268. https://doi.org/10.17660/ActaHortic.2018.1207.36

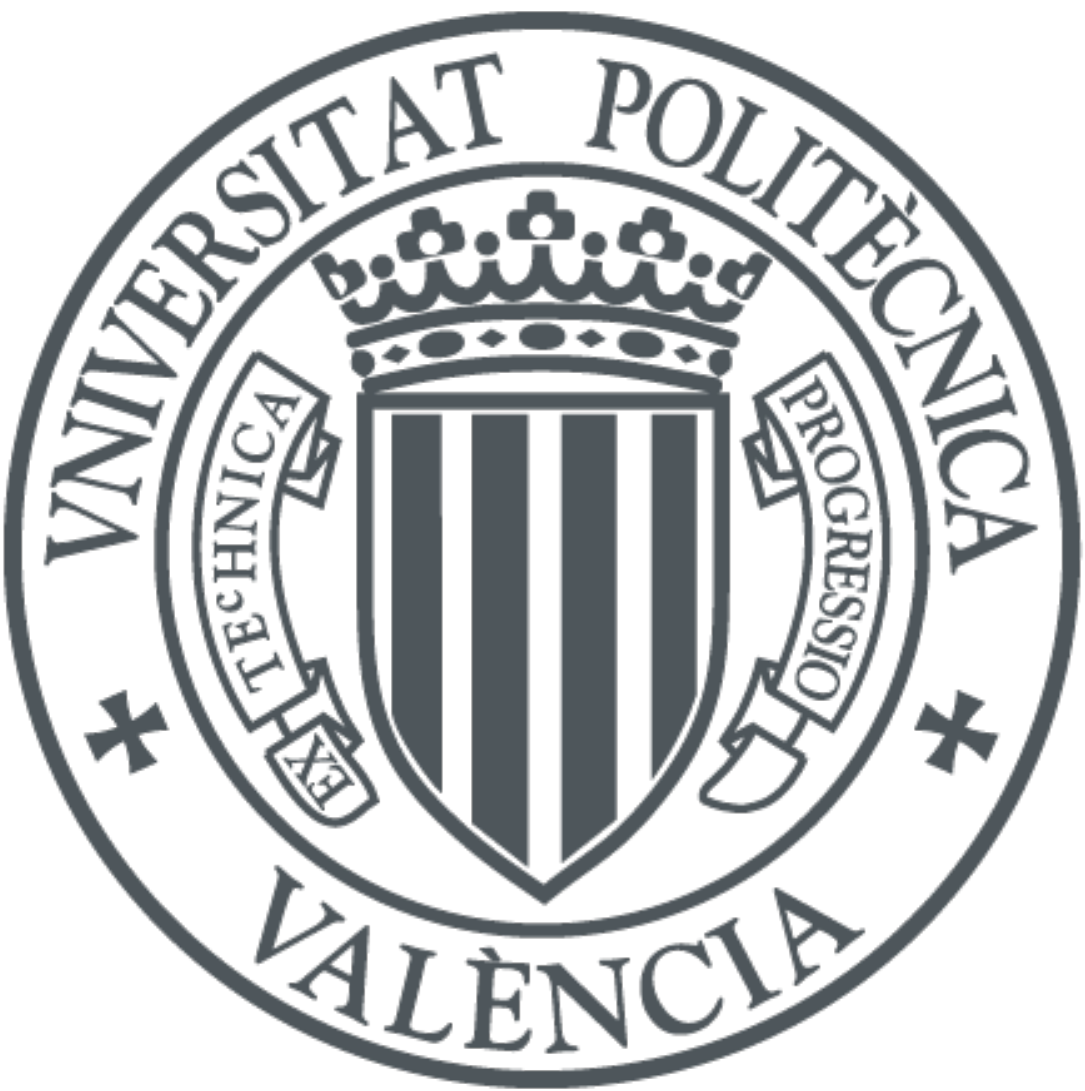

The final publication is available at

http://doi.org/10.17660/ActaHortic.2018.1207.36

Copyright International Society for Horticultural Science (ISHS)

Additional Information 


\title{
Parietaria mottle virus: a potential threat for tomato crop?
}

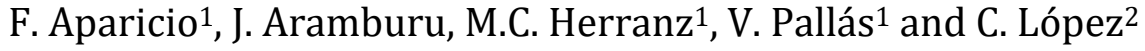 \\ ${ }^{1}$ Instituto de Biología Molecular y Celular de Plantas, IBMCP (Universitat Politècnica de València-Consejo Superior \\ de Investigaciones Científicas), Valencia, Spain; ${ }^{2}$ Instituto de Conservación y Mejora de la Agrodiversidad \\ Valenciana (COMAV), Universitat Politècnica de València, Valencia, Spain.
}

\begin{abstract}
Several isolates of Parietaria mottle virus (PMoV), a member of the Ilarvirus genus, have been described that affect tomato plants. These isolates, named as PMoV$T$, cause rings and a bright necrotic mosaic on young leaves that progresses to necrosis of the leaves, stem and apex, which may die. Fruits of affected plants display corky rings and brown patches, which develop into ridges with necrotic scars. The virus has been described to be present in tomato plants in several European countries such Italy, France, Greece and Spain. In addition, an outbreak of a necrosis disease of tomato in California in 2008 was shown to be caused by a new ilarvirus species related to PMoV. The genome of PMoV-T is composed of three single-stranded positive-sense RNAs. Nucleotide and amino acid sequence comparison of the RNA 3 of seven Spanish PMoV$T$ isolates with those of PMoV revealed important structural differences and a coat protein 16 amino acids shorter. Moreover a phylogenetic analysis of PMoV isolates from different host and geographical origins clustered in four different clades. Nonisotopic molecular hybridization, tissue printing hybridization, enzyme-linked immunosorbent assay (I-ELISA) and direct tissue-printing immunoassay using a polyclonal antiserum and one-step RT-PCR assays have been set up for routine detection of this virus. The virus was detected by I-ELISA in pollen extracts from Parietaria officinalis plants and transmitted mechanically to other species, including tomato and pepper. Besides, the virus was transmitted to other hosts using P. officinalis plants as a pollen source and several insect species such as thrips or mirids (used for biological control) in a nonpersistent manner. Although our results suggest that eliminating PMoV-infected $P$. officinalis plants that surround tomato crops could help restraining virus spread, further studies will be needed to prevent PMoV-T becoming a potential threat to tomato crops.
\end{abstract}

Keywords: Ilarvirus, mirids, Parietaria officinalis, PMoV, PMoV-T isolates, thrips

\section{INTRODUCTION}

Tomato (Solanum lycopirsicum L.) is grown all over the world, but the crop is vulnerable to a large number of economically important diseases, of which the diseases caused by viruses are of great importance owing to their rapidity of dissemination, their systemic nature, and their important effect on yield both qualitatively and quantitatively. One of the diseases caused by viruses resulting in important economic losses in tomato production is the caused by a strain of Parietaria mottle virus (PMoV). PMoV is a member of the genus Ilarvirus, family Bromoviridae, firstly reported in 1987 in Italia (Caciagli et al., 1989) and later in some countries of the Mediterranean basin.

Because of the large area of cultivated tomato worldwide and the frequent occurrence of PMoV epidemics in various countries, threatening tomato production, research efforts have concentrated on the study of the factors involved in the host-virus relationships in order to develop efficient control strategies. The objective of this review is to collect and systematize the information of horticultural relevance about $\mathrm{PMoV}$ which highlights the information 
available on various aspects of PMoV in tomato, including horticultural importance, molecular biology, study of the diversity among isolates by comparative sequencing, study of transmission, development of diagnostic methods (serological and molecular), and control strategies.

\section{DISCOVERY AND GEOGRAPHICAL DISTRIBUTION OF PMOV}

PMoV was first found in Italy in 1987 on plants of pellitory-of-the-wall (Parietaria officinalis L.) showing a bright yellow mosaic or mottling symptoms (Caciagli et al., 1989). Later, a tomato strain of PMoV, named PMoV-T, was detected in Piedmont (Ramaso et al., 1997; Lisa et al., 1998), although since 1971 PMoV-T had already been observed sporadically in this region. Subsequently PMoV-T was detected in other areas of Italy such as Apulia, Basilicata, Campania, Lazio, Liguria, Plugia, Sardinia and Sicily, and in. different regions of other countries, including southern France (Marchoux et al., 1999), northern Greece (Roggero et al., 2000) and the Mediterranean coast of Spain (Aramburu, 2001). More recently, an outbreak of a necrosis disease of tomato in California in 2008 was shown to be caused by a new ilarvirus species related to PMoV (Batuman et al., 2009), although further studies are needed to confirm this.

\section{HOST RANGE OF PMoV}

PMoV is primarily a virus of parietaria, but different strains of this virus have been found naturally infecting tomato (Ramaso et al., 1997; Lisa et al., 1998, Marchoux et al., 1999; Roggero et al., 2000; Aramburu, 2001), Mirabilis jalapa (family Nyctaginaceae) (Parrella, 2002) and pepper (Capsicum annuum) (Janssen et al., 2005). However, PMoV has wide host range and it can be sap transmitted by mechanical inoculation to other plant species, which are infected local or systemically, including cultivated and uncultivated plant species belonging to different families such as Solanaceae, Cucurbitacea, Fabaceae, Brassicaceae, Chenopodiaceae, Aizoaceae, Lamiaceae, Asteraceae, Malvaceae, Portulacaceae and Ranunculaceae (Caciagli et al., 1989; Roggero et al., 2000; Aramburu, 2001; Galipienso et al., 2005; Marchoux et al., 2008).

\section{PMOV SYMPTOMS IN TOMATO}

Symptoms of PMoV vary depending on the growth stage at the time of initial infection. On tomatoes, PMoV causes a wide range of symptoms that include a bright necrotic mosaic on leaves that progresses to necrosis of the leaves, stem and apex (Figure 1A-B), which may die (Figure 1C). After the first stages of infection, new symptomless shoots appear 15-30 days later (Figure 1D), and finally the plants demonstrate necrotic mosaic symptoms again. Fruits of affected plants display corky rings and brown patches on the surface, which develop into ridges with necrotic scars, which causes deformation of fruits and alteration of pigmentation (Figure $1 \mathrm{E}-\mathrm{G}$ ). Symptoms in naturally infected tomato plants in the early stages of infection are very similar to those caused by Tobacco streak virus (TSV), Tomato spotted wilt virus (TSWV) or Cucumber mosaic virus (CMV) carrying the CARNA 5 satellite (Lisa et al., 1998; Roggero et al., 2000; Aramburu et al., 2001; Galipienso et al., 2005).

Symptoms of PMoV in other naturally infected hosts include; yellow mosaic or mottling in parietaria (Lisa et al., 1998), mild mosaic leaf malformations of the upper leaves and necrotic line patterns in some of the basal in M. jalapa (Parrella, 2002) and necrotic stems and fruit with brown patches and corky rings on the surface in pepper (Janssen et al., 2005). 

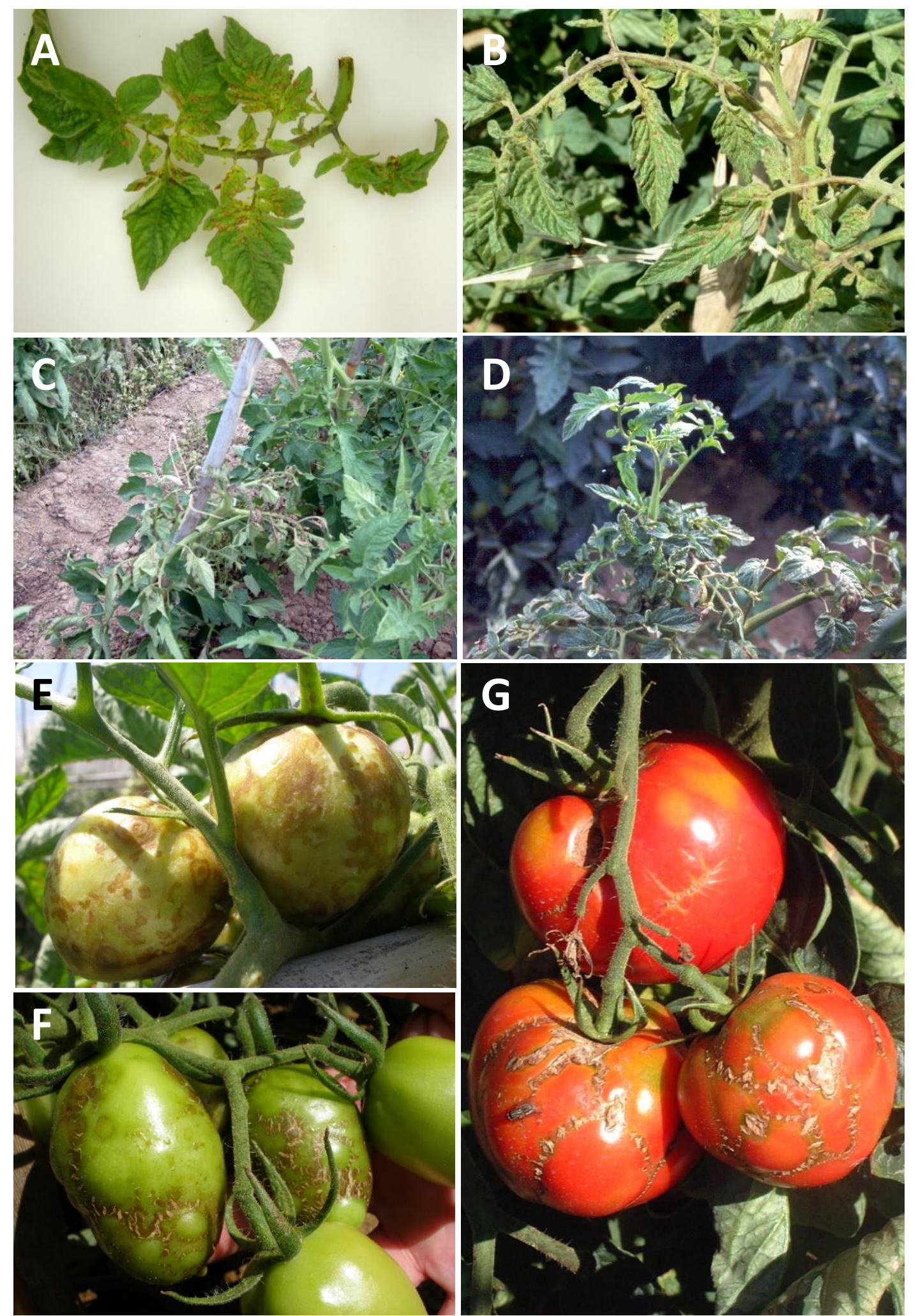

Figure 1. Symptoms of Parietaria mottle virus in tomato plants. $\mathbf{A}$ and $\mathbf{B}$, necrotic mosaic on leaves, stem and apex. C, dead apex. D, new symptomless shoots. E, F and G, corky rings and brown patches on the surface of the fruits. 


\section{GENOME ORGANIZATION}

PMoV belongs to Ilarvirus genus included in the alpha-like superfamily of viruses. Ilarviruses possess a tripartite genome of positive sense, single-stranded RNAs (ssRNAs) without a poly A tail (reviewed in Pallás et al., 2013) (Figure 2). The RNA 1 codes the subunit P1 of the replicase complex. The RNA 2 is bicistronic with the 5-proximal ORF encoding for the viral polymerase (P2) and a second ORF (ORF2b) located toward the 3 '-terminus of the molecule, which codes for a putative protein named $2 \mathrm{~b}$ protein. A subgenomic RNA derived from RNA2 (sgRNA4A) containing the ORF2b was found to accumulate in PMoV infected Chenopodium quinoa plants, although the $2 \mathrm{~b}$ protein has never been detected. A sgRNA4A was also detected in Nicotiana tabacum cv. Xanthi-nc plants infected with Spinach latent virus (SpLV) and moreover, a protein specie of the expected size for SpLV P2b was translated in vitro from virions containing the sgRNA 4A (Xin et al., 1998). However, a function for $2 \mathrm{~b}$ protein from PMoV and SpLV has to be yet demonstrated. It was proposed that ilar $2 \mathrm{~b}$ could be functionally similar to the Cucumber mosaic virus (CMV) $2 \mathrm{~b}$ protein, which is involved in viral movement and gene silencing. In this sense, a recent work showed that the $2 \mathrm{~b}$ protein from other ilarvirus (Asparagus virus-2) functions as an RNA silencing suppressor (Shimura et al., 2013). The RNA 3 is bicistronic coding for the movement protein (MP) (proximal ORF), and the coat protein (CP) (distal ORF). The MP is required for virus cell-to-cell movement and in contrast with the rest of ilarviruses contains two RNA binding regions. A mutational analysis reported that basic residues in both regions are critical for RNA binding and targeting the MP at plasmodesmata (Martinez et al., 2014). In Ilarviruses CP is expressed via a subgenomic RNA 4 which is transcribed from an internal promoter region within the genomic RNA 3. The CP is a multifunctional protein implicated in replication, translation, virion formation and systemic movement. Indeed, alfamo- and ilarviruses require the presence of $\mathrm{CP}$ in the inoculum to establish the infection. This phenomenon is denominated "genome activation" and involves the interaction of the $\mathrm{CP}$ with the 3 '-terminal non-translated regions of viral RNAs (Pallás et al., 2013).

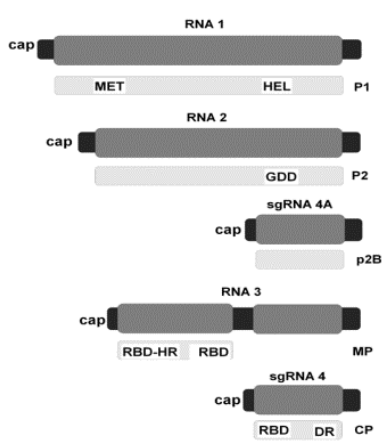

Figure 2. Diagram showing the genome organization of PMoV. Genomic RNAs 1, 2, 3 and subgenomic (sg) RNA 4 and 4A are presented as grey light and dark boxes for ORF RNAs and non-translated regions, respectively. White boxes represent viral proteins P1, P2, p2b, MP and CP. Characteristic domains Methyltransferase (MET), Helicase (HEL), RNA-dependent RNA polymerase (GDD), RNA Binding Domain (RBD), Hydrophobic Region (HR) and Dimerization Region (DR) are indicated.

\section{MOLECULAR VARIABILITY}

The analysis of the molecular variability of plant virus populations provide information of their potential for variation and consequently to set up strategies for the control of these pathogens (García-Arenal et al., 2001). Until now, only the complete genomes of three isolates have been sequenced: the Italian Pe1, infecting P. officinalis (Ge and Scott, 1996; Scott, et al., 2006)) and the Spanish CR8 and Italian T32, infecting tomato (Galipienso et al., 2009; 
Martínez et al., 2015). The nucleotide identities of the T32 genomic RNAs were higher with the Italian Pe1 isolate $(96.24,94.01$, and $96.69 \%$ for RNA1, RNA2, and RNA3, respectively) than with those of the Spanish CR8 isolate $(92.63,90.48$, and 93.78\% for RNA1, RNA2, and RNA3, respectively) (Martínez et al., 2015). Also, in previous studies, it was reported the existence of two CP variants as consequence of a cytosine deletion in the ORF of the CP that results in a different start codon. Thus, most PMoV isolates present a CP size of 204 amino whereas two isolates (Pe1 and ST-1 both collected in Italy) have a CP of 220 amino acids (Galipienso et al., 2008; 2009; 2015). Furthermore, a recent phylogenetic analysis of the PMoV CP of several isolates collected in Spain, Italy and Greece clustered the isolates in one clade exclusively composed of Italian isolates and three clades which included Spanish and Greek isolates. These clades were not related with host specificity since isolates obtained from tomato grouped in different clades (Galipienso et al., 2015).

\section{TRANSMISSION AND SPREAD OF PMoV}

The distribution of tomato plants infected by PMoV tends to be located either in the proximity of greenhouse entrances or in the vicinity of a large number of $P$. officinalis plants growing at the margins of the fields (Ramasso et al., 1997). This was taken to indicate that PMoV spreads into tomato from infected $P$. officinalis, probably by means of some insect vector. Initially, the presence of PMoV was detected by indirect ELISA in pollen extracts from symptomatic $P$. officinalis and tomato plants collected from commercial fields. Following the discovery that pollen could be important in transmission, $\mathrm{PMoV}$ was found to be transmitted to several experimental hosts using seven insect species, members of five different families, and $P$. officinalis infected plants as a pollen source (Aramburu et al., 2010). Transmission occurred if the insects carried the pollen on their bodies, or if the pollen was dusted onto the test plants before introducing the insects. Transmission was non-persistent, not very efficient, and it was rare if flowers of infected $P$. officinalis plants had previously been removed or when alternative hosts that produced smaller quantities of pollen were used. No transmission was obtained when $P$ officinalis $\mathrm{PMoV}$ infected pollen was dusted onto the test plants in the absence of insects. A strain of PMoV was also transmitted by contaminated pollen from tomato to tomato after mechanical injury that thrips inflict on flowers during feeding (Marchoux et al., 2008). A similar mode of transmission involving thrips feeding on infected pollen has been described for Tobacco streak virus transmission to tomatoes in the field (Sdoodee and Teakle, 1993). Although the precise mechanism involved in PMoV dissemination under field conditions is yet to be determined, all results published to date indicate that pollen from PMoV-infected $P$. officinalis could serve as a means for PMoV spreading to other plant species. The direct intervention of phytophagous insects (some of them used for biological control) would be necessary to cause lesions by feeding or otherwise so as to facilitate the exposure of cell protoplasm to infected pollen (Aramburu et al., 2010).

In addition, $36 \%$ of the seedlings derived from seed of infected $P$. officinalis plants were shown to be infected with PMoV (Aramburu et al., 2010), but none of the germinated seedlings of tomato (Ramasso et al., 1997). Moreover, PMoV can be successfully transmitted by mechanical inoculation to a wide host range, although the mechanical transmission efficiency to tomato plants was poorly sap transmitted (Aramburu et al., 2010).

\section{DEVELOPMENT OF METHODS FOR DETECTING PMOV}

Surveys carries out in tomato crops in north-eastern Spain showed that PMoV detection in P. officinalis by different molecular approaches rendered inconsistent results and infected plants could only be confirmed by mechanical transmission to C. quinoa plants and subsequent detection in that host by enzyme-linked immunosorbent assay (I-ELISA) (Galipienso at al., 2005). On the other hand, routine detection procedures of PMoV in cultivated crops have been developed by means of biological and molecular approaches 
(Figure 3). Respect to the biological procedures, PMoV can be detected by inoculating onto several herbaceous plants as N. tabacum cv. Xanti-nc, $N$. benthamiana, N. clevelandii, $N$. glutinosa, Datura stramonium and C. quinoa. The symptoms in these plants consist mainly in necrotic lesions and chlorotic mosaic in inoculated leaves and systemic infection in some host. However, it is important assaying in different indicator hosts since there has been reported PMoV-T isolates infecting $N$. benthamiana and $N$. clevelandii but not $N$. glutinosa, N. tabacum cv. Xanthi-nc or D. stramonium (Galipienso et al., 2008).

In the case of the molecular approaches, a polyclonal antibody was developed that permitted to detect the virus in tomato infected plants by I-ELISA and direct tissue-printing immunoassay (Aparicio et al., 2009a). On the other hand molecular techniques as one-step RT-PCR assays with specific set of primers and non-isotopic hybridization using digoxigeninlabelled riboprobes were developed to detect the virus in shoots, leaves and fruits by dot-blot and direct tissue-printing hybridization (Galipienso et al., 2005; Aparicio et al., 2009b). Both molecular procedures were highly specific, and no cross-reactions were observed with other related ilarviruses. In contrast to the observed with Prunus necrotic ringspot virus (SánchezNavarro et al., 1998) non-isotopic molecular hybridization was more robust than one-step RT-PCR when analyzed tomato plants collected from commercial fields. Besides tissueprinting hybridization could show high reliability which would facilitate both the large-scale analysis and epidemiological studies of this pathogen (Galipienso et al., 2005).

A

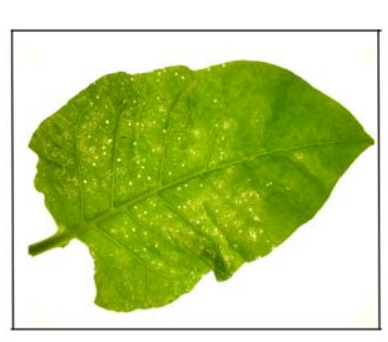

C

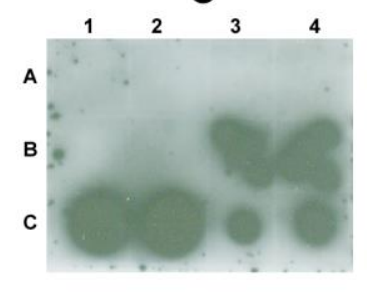

B

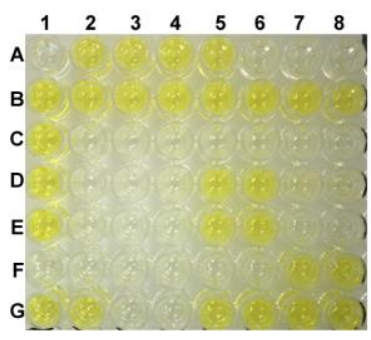

D

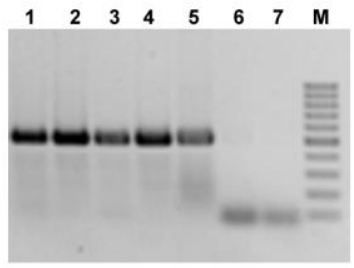

Figure 3. Illustration of the different approaches currently used to detect PMoV Infected plants. (A) Image of a N. tabacum cv. Xanthi-nc leaf infected with PMoV showing the characteristic necrotic spots. (B) I-ELISA plate of the analysis of tomato plants. Samples A7 and A8 were the negative controls. (C) Non-isotopic hybridization of tomato samples by direct tissue-printing (samples B3 and B4) or total nucleic acid extraction (samples C1 to C4). Samples A1 and A2 were the negative controls. (D) RT-PCR analysis of tomato plants with PMoV specific primers to amplify a fragment of the CP ORF. Lanes 6 and 7 corresponded to negative controls. M, molecular marker.

\section{CONTROL MEASUREMENTS OF PMOV}

Breeding resistant cultivars is the most promising method for viral disease control, but requires the identification of sources of resistance. However, the search for PMoV resistance in tomato accessions has not been a primary goal in the affected countries, possibly due to the 
absence of a protocol that ensures efficient and reliable mechanical transmission. Successful inoculation of PMoV to individual plants is necessary to evaluate the level of resistance of tomato genotypes that may be used in breeding programs and to our knowledge no resistance has been described to PMoV in Solanum genus.

In this case, cultural practices are an essential element of a sustainable approach to manage the disease caused by PMoV. The incidence of PMoV could be reduced by removing $P$. officinalis plants around tomato crops. The fact, in a tomato plot exhibiting an abnormally high rate of infection over two consecutive years $(24 \%$ and $9.2 \%)$, the incidence of PMoV decreased to less than $1 \%$ after the removal of all $P$. officinalis plants in the surrounding area of the crop (Aramburu et al., 2010). The application of this cultural practice would avoid the indiscriminate control of insects that transmit $\mathrm{PMoV}$, which is essential if we consider that mirids are predator species frequently used as biological control agents in Spain.

\section{CONCLUSIONS}

The following conclusions can be drawn from the review:

- P. officinalis is a perennial plant commonly present around the tomato fields and it is the main weed specie that acts as a reservoir of the virus, although it shows no symptoms with most of the PMoV-T isolates.

- In infected P. officinalis plants seed transmission occurs allowing the maintenance of infection in the field over time, although it cannot be ruled out any further transmission by cross-pollination between plants of this species.

- The virus can be transmitted nonspecifically through pollen from infected plants to various host species, in which pollen acts as vector and the intervention of different insect species as inoculating agents.

- The results currently available suggest that eliminating PMoV-infected $P$. officinalis plants that surround tomato crops could help restraining virus spread. However, as consequence of the high mutational rate of viruses the appearance of dangerous isolates for tomato and other horticultural crops cannot be ruled out.

\section{ACKNOWLEDGEMENTS}

\section{Literature cited}

Aparicio, F., Aramburu, J., Soler, S., Galipienso, L., Nuez F., Pallás V., and López, C. (2009a). Immunodiagnosis of parietaria mottle virus in tomato crops using a polyclonal antiserum against its coat protein expressed in a bacterial system. J. Phytopathol. 157, 511-513 doi: 10.1111/j.1439-0434.2008.01511.x.

Aparicio, F., Soler, S., Aramburu, J., Galipienso, L., Nuez F., Pallás V., and López, C. (2009b). Simultaneous detection of six RNA plant viruses affecting tomato crops using a single digoxigenin-labelled polyprobe. Eur. J. Plant Pathol. 123, 117-123 doi: 10.1007/s10658-008-9347-5.

Aramburu, J. (2001). First report of Parietaria mottle virus on tomato in Spain. Plant Dis. 85, 1210 http://dx.doi.org/10.1094/PDIS.2001.85.11.1210C.

Aramburu, J., Galipienso, L., Aparicio, F., Soler, S., and López, C. (2010). Mode of transmission of parietaria mottle virus. J. Plant Pathol. 92, 679-684 doi: 10.4454/jpp.v92i3.313.

Batuman, O., Miyao, G., Kuo, Y.W., Chen, L.F., Davis, R.M., and Gilbertson, R.L. (2009). An outbreak of a necrosis disease of tomato in California in 2008 was caused by a new ilarvirus species related to Parietaria mottle virus. Plant Dis. 93, 546 http://dx.doi.org/10.1094/PDIS-93-5-0546C.

Caciagli, P., Boccardo, G., and Lovisolo O. (1989). Parietaria mottle virus, a possible new ilarvirus from Parietaria officinalis (Urticaceae). Plant Pathol. 38, 577-584 doi: 10.1111/j.1365-3059.1989.tb01454.x.

Galipienso, L., Herranz, M.C., López, C., Pallás, V., and Aramburu, J. (2008). Sequence analysis within the RNA 3 of seven Spanish tomato isolates of parietaria mottle virus (PMoVT) reveals important structural differences with parietaria isolates (PMoV). Eur. J. Plant Pathol. 120, 125-135 http://dx.doi.org/10.1007/s10658-007-9200-2. 
Galipienso, L., Herranz, M.C., Pallás, V., and Aramburu, J. (2005). Detection of a tomato strain of Parietaria mottle virus (PMoV-T) by molecular hybridization and RT-PCR in field samples from north-eastern Spain. Plant Pathol. 54, 29-35 doi: 10.1111/j.1365-3059.2004.01109.x.

Galipienso, L., Martínez, C., Willemsen, A., Alfaro-Fernánndez, A., Font-San Ambrosio, I., Davino, S., and Rubio, L. (2015). Genetic variability and evolutionary analysis of parietaria mottle virus: role of selection and genetic exchange. Arch. Virol. 160, 2611-2616 doi: 10.1007/s00705-015-2550-8.

Galipienso, L., Rubio, L., López, C., Soler, S., and Aramburu, J. (2009). Complete nucleotide sequence of a Spanish isolate of parietaria mottle virus infecting tomato. Virus Genes 39, 256-260 http://dx.doi.org/10.1007/s11262009-0388-4.

García-Arenal F, Fraile A, Malpica JM (2001) Variability and genetic structure of plant virus populations. Annu. Rev. phytopathol. 39, 157-186.

Ge, X., and Scott, S.W. (1996). The nucleotide sequence of hydrangea mosaic virus RNA 3 exhibits similarity with the RNA 3 of tobacco streak virus. Virus Res. 40, 57-63 http://dx.doi.org/10.1016/0168-1702(95)01251-6.

Janssen, D., Saez, E., Segundo, E., Martín, E., Gil, F., and Cuadrado, I.M. (2005). Capsicum annum-a new host of Parietaria mottle virus in Spain. Plant Pathol. 54, 567 doi: 10.1111/j.1365-3059.2005.01195.x.

Lisa, V., Ramasso, E., Ciuffo, M., and Roggero, P. (1998). Apical necrosis of tomato caused by a strain of Parietaria mottle Ilarvirus. Proceedings 9 th Conference of the International Society for Horticultural Science. VVWG, Recent advances in vegetable virus research, Turin, 290-291.

Martínez, C., Coll-Bonfill, N., Aramburu, J., Pallás, V., Aparicio, F., and Galipienso, L. (2014). Two basic (hydrophilic) regions in the movement protein of parietaria mottle virus have RNA binding activity and are required for cell-to cell transport. Virus Res. 184, 54-61 http://dx.doi.org/10.1016/j.virus res.2014.02.008.

Martínez, C., Aramburu, J., Rubio, L., and Galipienso, L. (2015). Complete genome sequence of a tomato isolate of parietaria mottle virus from Italy. Genome Announc. 3(6), e01452-15 doi:10.1128/genomeA.01452-15.

Marchoux, G., Parella, G., Gebre-Selassie, K., and Ganglon, P. (1999). Identification de deux ilarvirus sur tomate dans le sud de la France. Phytoma 522, 53-55.

Marchoux, G., Gognalons, P., and Gebre-Selassie, K., eds. (2008). Virus des Solanacées. Du genome viral à la protection des cultures (Versailles, France: Editions Quae), pp.858.

Pallás, V., Aparicio, F., Herranz, M.C., Sánchez-Navarro, J.A., and Scott, W. (2013). The molecular biology of ilarviruses. Adv. Virus Res. 87, 139-81 http://dx.doi.org/10.1016/B978-0-12-407698-3.00005-3.

Parrella, G. (2002). First report of Parietaria mottle virus in Mirabilis jalapa. Plant Pathol. 51, 401 doi: 10.1046/j.1365-3059.2002.00717.x.

Ramasso, E., Roggero, P., Dellavalle, G., and Lisa, V. (1997). Necrosi apicale del pomodoro causata da un ilarvirus. Informatore Fitopatologico 1, 71-77.

Roggero, P., Ciuffo, M., Katis, N., Alioto, D., Crescenzi, A., Parella, G., and Gallitelli, D. (2000). Necrotic disease in tomatoes in Greece and south Italy caused by tomato strain of Parietaria mottle virus. J. Plant Pathol. 82, 159.

Sánchez-Navarro, J.A., Aparicio, F., and Pállas, V. (1998) Comparative analysis of ELISA, nonradioactive molecular hybridization and PCR for the detection of prunus necrotic ringspot virus in herbaceous and Prunus hosts. Plant Pathol. 47, 780-786 doi: 10.1046/j.1365-3059.1998.00301.x.

Scott, S.W., Zimmerman, M.T., and Rankin, D. (2006). Complete sequence of the RNA 1 and RNA 2 of parietaria mottle virus. Arch Virol. 151, 1895-1898 http://dx.doi.org/10.1007/s00705-006-0803-2.

Sdoodee, R., and Teakle, D.S. (1993). Studies on the mechanism of transmission of pollen-associated Tobacco streak ilarvirus by Thrips tabaci. Plant Pathol. 42, 88-92 doi: 10.1111/j.1365-3059.1993.tb01473.x.

Shimura, H., Masuta. C., Yoshida. N., Sueda. K., Suzuki. M. (2013). The $2 b$ protein of Asparagus virus 2 functions as an RNA silencing suppressor against systemic silencing to prove functional synteny with related cucumoviruses. Virology 442, 180-188 http://dx.doi.org/10.1016/j.virol.2013.04.015.

Xin, H.W., Ji, L.H., Scott, S.W., Symons, R.H., and Ding, S.W. (1998). Ilarviruses encode a cucumovirus-like $2 \mathrm{~b}$ gene that is absent in other genera within the Bromoviridae. J. Virol. 72, 6956-6959. 